\title{
GLP-1(7-36)AMIDE: CHARACTERIZATION OF ITS BINDING TO SPECIFIC RECEPTORS IN NORMAL AND TUMORAL RAT ISLET CELLS
}

\author{
Isabel Valverde, Sonsoles Garcia, Carmen Ruiz-Grande, Eunate Furundarena, Maria A. \\ Trapote and Maria L. Villanueva-PeÑaCarrillo \\ Departamento Metabolismo, Nutrición y Hormonas, Fundación Jiménez Díaz, Madrid 28040, Spain
}

\begin{abstract}
We have studied the binding of ${ }^{125} \mathrm{I}-\mathrm{GLP}-1(7-36)$ amide to normal rat islet cells and rat insulinoma-derived RINm5F cells, and found it is time- and temperature-dependent, and directly proportional to cell concentration. In both cell types, the Scatchard plot demonstrates the presence of high- and low-affinity binding sites. The 50\% inhibition of the maximal binding to $0.4 \mathrm{nM}^{125} \mathrm{I}-\mathrm{GLP}-1$ (7-36)amide was obtained when cells were incubated in the presence of about $3.0 \mathrm{nM}$ of unlabelled peptide. Glucagon, oxyntomodulin and GLP-1(736)amide at high concentrations $(10 \mu \mathrm{M})$ do not compete with the ${ }^{125}$ I-GLP-1(7-36)amide binding. In pancreatic tumoral cells there seems to be a direct correlation between the maximal binding, the number of high-affınity binding sites and the amount of intracellular insulin.
\end{abstract}

The proglucagon structure of several mammalian, deduced from the genome sequence or the sequence of cloned DNA complementary to proglucagon mRNA, has been documented $(1,7)$; the mRNA that codes for proglucagon, the 160 amino acids glucagon precursor, is similar in all mammalian species studied. The proglucagon mRNA is identical in pancreas and intestine (12) but the pathway of post-translational processing of the primary transcript differs markedly in the two tissues (10). In the pancreas, the prohormone is processed to proglucagon 1-30, glucagon, proglucagon 64-69 and the $\mathrm{COOH}$-terminal fragment (proglucagon $72-158$ ); in the small intestine, the prohormone is processed to glicentin (proglucagon 1-69), GLP-1, proglucagon $111-123$ and GLP-2 (10). The $\mathrm{COOH}$-terminal residue of GLP-1 and of the intervening sequence, proglucagon $111-123$, can be $\alpha$ amidated $(10,13)$.

Characterization of GLP-1 from intestinal extracts has documented that this peptide is further processed to truncated forms GLP-1(7-37) and/or GLP-1(7-36)amide $(11,13)$; both, synthetic GLP1(7-37) and GLP-1(7-36)amide have shown a strong insulinotropic effect in isolated perfused pig (8) and rat (17) pancreas, while the full length GLP$1(1-37)$ molecule does not seem to equally affect the insulin secretion (17).

The presence of specific receptors for GLP-1(736)amide has been documented in two different cloned rat insulin-producing tumoral cells $(6,14)$; further studies demonstrate that the signal transmission after GLP-1(7-36)amide binding is facilitated by the adenylate cyclase system (5), yet, specific information is lacking on normal islet cells. The RIMm5F cell line is derived from a radiationinduced insulin-producing rat pancreatic tumor (3) which retains many of the differentiated functions of pancreatic B cells (19). In this study, we have examined the specific binding of ${ }^{125}$ I-GLP-1(736)amide to dispersed normal rat pancreatic islet cells as well as to tumoral cells of the RINm5F line.

\section{MATERIALS AND METHODS}

\section{Cell Line}

Tumoral islet cells of the RINm5F line were cultured, harvested and counted as previously de- 
scribed (4). Except otherwise mentioned, groups of $1 \times 10^{6}$ cells were incubated for $30 \mathrm{~min}$ at $37^{\circ} \mathrm{C}$ in $0.1 \mathrm{ml}$ of a buffered medium $[25 \mathrm{mM}$ Tris $\mathrm{HCl}$, $120 \mathrm{mM} \mathrm{NaCl}, 1.2 \mathrm{mM} \mathrm{MgSO}_{4}, 5 \mathrm{mM} \mathrm{KCl}, 1 \mathrm{mM}$ EDTA, $10 \mathrm{mM}$ glucose, $15 \mathrm{mM} \mathrm{CH} \mathrm{CHOONa}_{3}$, $\%$ bovine serum albumin and bacitracin $(4 \mathrm{mg} / \mathrm{ml})$, $\mathrm{pH}, 7.6]$ containing $0.4 \mathrm{nM}{ }^{125} \mathrm{I}-\mathrm{GLP}-1(7-36)$ amide (Peninsula Laboratories) radiolabelled in our laboratory by the chloramine $\mathrm{T}$ method, and the mono- ${ }^{125}$ I-GLP-1(7-36)amide, was separated by HPLC (16).

After incubation, cells were rapidly centrifuged (1 min at 1,500 rpm in a Beckman microfuge-12) and washed twice with $0.5 \mathrm{ml}$ of iced non-radioactive medium; then, each cell pellet was examined for its gamma radioactive content. The non-specific binding was that obtained in the presence of $1 \mu \mathrm{M}$ unlabelled GLP-1(7-36)amide.

\section{Islet Cells}

Dispersed islet cells were prepared from pancreatic islets (15), previously isolated by the collagenase technique, from fed albino rats $(200-250 \mathrm{~g})$. Prior to the experiment, islet cells were cultured overnight in the same conditions as the RINm5F cells (4).

For binding studies, groups of $0.25 \times 10^{6}$ cells were treated following the same procedure as described for RINm5F cells.

\section{Calculations}

The specific binding was determined by subtracting, from the total cell-associated radioactivity, the non-specific binding obtained in the presence of $1 \mu \mathrm{M}$ unlabelled GLP-1(7-36)amide, which represented $1.68 \pm 0.28 \quad(n=15)$, and $1.72 \pm 0.13 \quad(n=46)$ percent of the total radioactivity for $0.25 \times 10^{6}$ normal cells and $1.0 \times 10^{6}$ RINm5F cells, respectively. Results are expressed as the mean value ( \pm SEM), and the number of individual determinations ( $n$ ) is stated.

\section{RESULTS}

\section{RINm5F Cells}

The specific binding of ${ }^{125}$ I-GLP-1(7-36)amide $(0.4 \mathrm{nM})$ to tumoral islet cells was time- and temperature-dependent, reaching the maximal at $30 \mathrm{~min}$ and $37^{\circ} \mathrm{C}$ (Fig. $1 \mathrm{~A}$ ).

When cells were first exposed for $30 \mathrm{~min}$ to ${ }^{125} \mathrm{I}-$

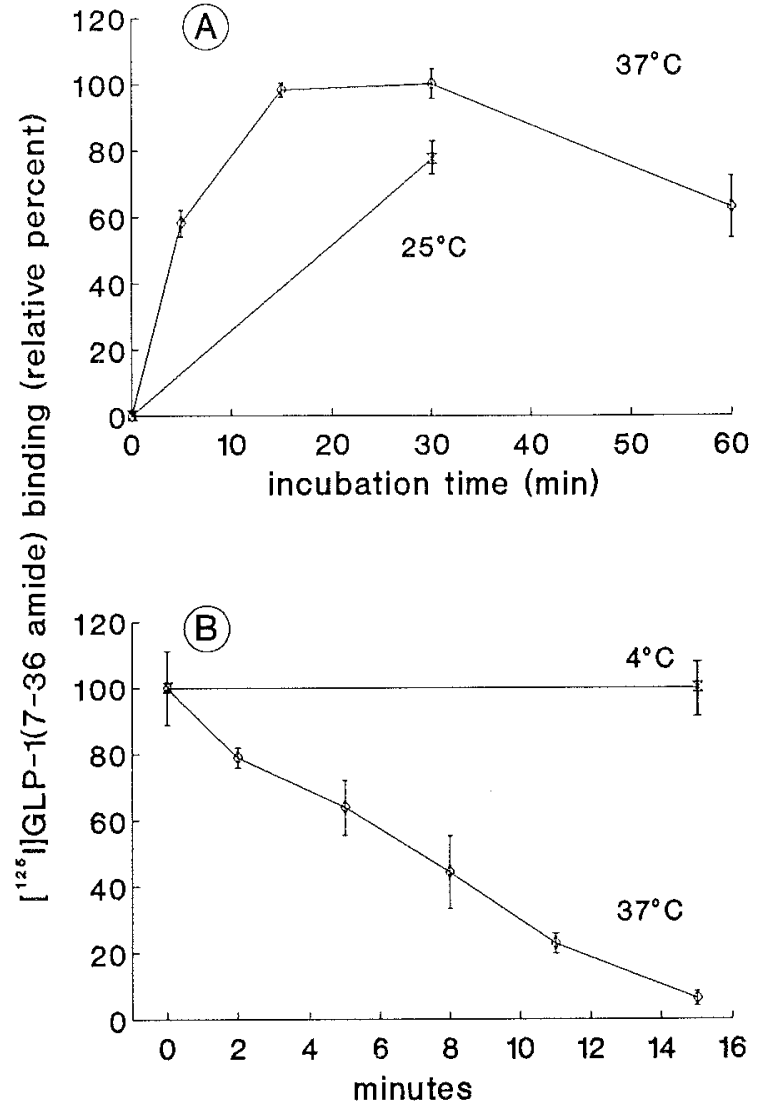

Fig. 1 A: Relative specific binding of ${ }^{125}$ I-GLP-1(736)amide $(0.4 \mathrm{nM})$ to rat RINm5F cells $\left(1 \times 10^{6}\right.$ cells/ $100 \mu \mathrm{l})$ at $25^{\circ} \mathrm{C}$ and $37^{\circ} \mathrm{C}$ as function of time. B: Dissociation of the $30 \mathrm{~min} 37^{\circ} \mathrm{C}$. ${ }^{125} \mathrm{I}$-GLP-1(7-36)amide binding to rat RINm $5 \mathrm{~F}$ cells $\left(1 \times 10^{6}\right.$ cells $\left./ 100 \mu \mathrm{l}\right)$ at $4^{\circ} \mathrm{C}$ and $37^{\circ} \mathrm{C}$. Data are shown as mean \pm SEM ( $n=6-12$ for $A$ and $n=3-10$ for $B$ ).

GLP-1(7-36)amide (0.4 nM), washed once, and then incubated for 1 to $20 \mathrm{~min}$ at $37^{\circ} \mathrm{C}$ in the sole presence of unlabelled GLP-1(7-36)amide $(1 \mu \mathrm{M})$, $50 \%$ of the cell-associated radioactivity was released within the first $7 \mathrm{~min}$ (Fig. 1B). In these experiments, the non-specific binding was measured in cells previously incubated in $1 \mu \mathrm{M}$ GLP-1(736)amide, and then treated in the same manner. Results were identical when dissociation was carried out with no addition of unlabelled GLP-1(736)amide in the second incubation (data not shown).

Incubation of increasing RINm5F cell concentrations with ${ }^{125}$ I-GLP-1(7-36)amide, showed a proportional specific binding in a cell range of 0.25 to $0.75 \times 10^{6} \mathrm{cells} / 100 \mu \mathrm{l}$, whereas higher cell concen- 
Table 1 Specific Binding of ${ }^{125}$ I-GLP-1(7-36)Amide $(0.4 n M)$ to $1 \times 10^{6}$ High $(n=6)$ and Low $(n=33)$ Insulin Content RINmSF Cells

\begin{tabular}{ccc}
\hline $\mathrm{N}$ & $\begin{array}{c}\text { Insulin content } \\
\text { ng/ } 10^{6} \text { cells }\end{array}$ & $\begin{array}{c}{ }^{25} \mathrm{I}-\mathrm{GLP}-1(7-36) \text { amide }(0.4 \mathrm{nM}) \\
\% \text { bound }\end{array}$ \\
\hline 6 & $236.4 \pm 6.10$ & $4.05 \pm 0.60$ \\
33 & $1.9 \pm 0.58^{*}$ & $1.11 \pm 0.20^{*}$ \\
\hline
\end{tabular}

Data are expressed as mean \pm SEM. $* P<0.001$

tration $\left(1 \times 10^{6}\right.$ cells $\left./ 100 \mu 1\right)$ was out of line.

Although the protein content of RINm5F cells remains fairly stable in distinct sub-lines, the insulin content displays wide variations (18). The specific maximal binding $\left[0.4 \mathrm{nM}{ }^{125} \mathrm{I}\right.$-GLP-1(736)amide] was higher $(1.62 \pm 0.24, \mathrm{n}=6$, fmol bound $/ 10^{6}$ cells) for cells with high insulin content (236.4 $\pm 6.1 \mathrm{ng} / 10^{6}$ cells) than for those with low insulin content $\left(1.9 \pm 0.58 \mathrm{ng} / 10^{6}\right.$ cells $)$ in which, the amount of GLP-1(7-36)amide bound was $0.44 \pm 0.07, \mathrm{n}=33, \mathrm{fmol} / 10^{6}$ cells (Table 1 ).

In tumoral cells, the Scatchard plot of data collected at increasing concentrations of added GLP$1(7-36)$ amide $\left(10^{-10}\right.$ to $\left.10^{-7} \mathrm{M}\right)$ demonstrated the presence of high- and low-affınity binding sites. The apparent $\mathrm{Kd}$ of the high affinity binding sites was $1.0 \mathrm{nM}$ and $4.0 \mathrm{nM}$ for the low and high insulin content cells, respectively, and the $\mathrm{Kd}$ of the low-affinity binding sites was $170 \mathrm{nM}$ and $26 \mathrm{nM}$ for the low and high insulin content cells, respectively (Fig. 2); these data, represented by displacement curves, are shown in Fig. 3. The 50\% binding inhibition was close to $10^{-9} \mathrm{M}$ GLP-1(7-36)amide in low insulin content tumoral cells, and close to $10^{-8} \mathrm{M}$ in those with high insulin content; nevertheless, this difference was not statistically signif1cant.

Crystalline porcine glucagon (Lilly Research Laboratories) and synthetic GLP-1(1-36)amide and oxyntomodulin with Lys in position 33, both from Peninsula Laboratories, at high concentrations $(0.1 \mu \mathrm{M})$, did not compete with the ${ }^{125}$ I-GLP1(7-36)amide binding.

\section{Normal Islet Cells}

In normal rat dispersed pancreatic cells, the specific binding at $30 \mathrm{~min}$ incubation at $37^{\circ} \mathrm{C}$ in the presence of $0.4 \mathrm{nM}{ }^{125} \mathrm{I}$-GLP-1(7-36)amide, averaged $0.45 \pm 0.15 \mathrm{fmol}$ GLP-1(7-36)amide bound $/ 10^{6}$ cells.

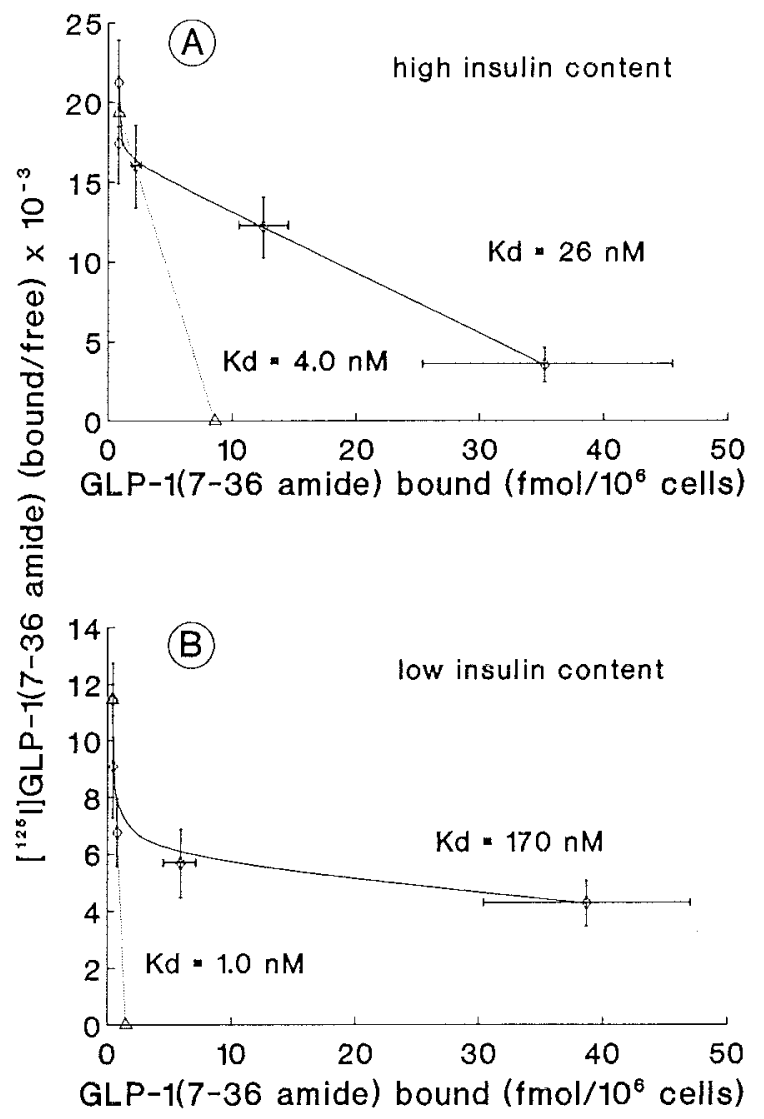

Fig. 2 Scatchard plots of the specific binding of ${ }^{125} \mathrm{I}$ GLP-1(7-36)amide to high (A) and low (B) insulin content rat RINm5F cells $\left(1 \times 10^{6}\right.$ cells $\left./ 100 \mu \mathrm{l}\right)$. Data are shown as mean \pm SEM ( $n=6$ for $A$ and $n=15-33$ for $B$ ).

The Scatchard plot of data collected at increasing concentrations of added GLP-1(7-36)amide $\left(10^{-10}\right.$ to $10^{-7} \mathrm{M}$ ) demonstrated the presence of high- and low-affinity binding sites (Kd $1.8 \mathrm{nM}$ and $460 \mathrm{nM}$, respectively) (Fig. 4B). The 50\% inhibition was seen to occur at $10^{-9} \mathrm{M}$ GLP-1(7-36)amide when the same data were represented as a displacement curve (Fig. 4A).

\section{DISCUSSION}

Our results demonstrate that normal insulin-producing cells contain specific receptors for GLP-1(736)amide, and indicate also that both, normal and tumoral cells, present two different binding sites, a high- and a low-affinity, being the high-affinity one similar to that described by Göke and Conlon in RINm5F line (6).

As the GLP-1(7-36)amide concentration re- 


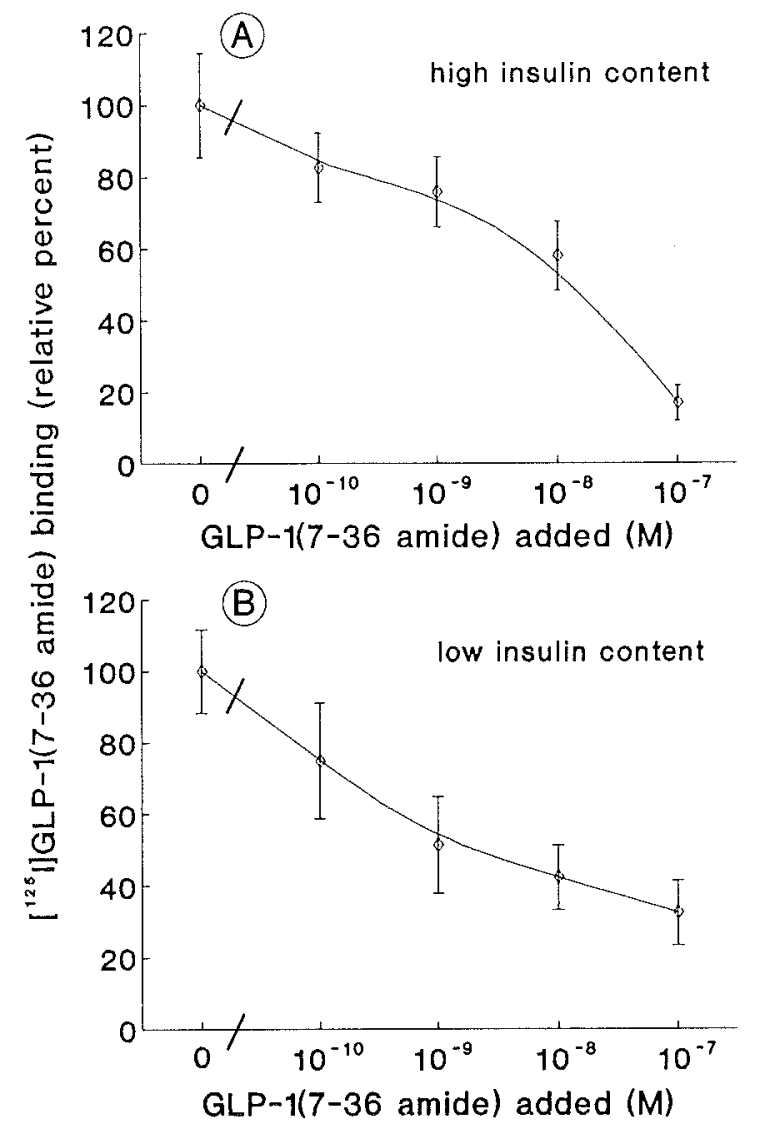

Fig. 3 Displacement of the specific binding of ${ }^{125} \mathrm{I}-$ GLP-1(7-36)amide to rat high (A) and low (B) insulin content RINm5F cells $\left(1 \times 10^{6}\right.$ cells $\left./ 100 \mu 1\right)$ by increasing concentration of GLP-1(7-36)amide $\left(0-10^{-7} \mathrm{M}\right)$. Data are shown as mean \pm SEM $(n=6$ for $A$ and $n=15-33$ for B).

quired for half maximal binding, in normal rat islet cells, was close to $10^{-9} \mathrm{~mol} / \mathrm{l}$, an insulinotropic dose (17) not much higher than the stimulated postprandial plasma levels (9), our findings support the suggested role of GLP-1(7-36)amide in the physiological regulation of insulin release $(8,9)$.

The data obtained from the two tumoral cell sublines, which differed in their insulin content, suggest a direct correlation between the maximal binding and the amount of intracellular insulin, associated with the high-affinity binding sites.

Glucagon is known to stimulate insulin release and the presence of receptors for glucagon has been demonstrated on insulinoma (RINm5F) cells (2); yet, glucagon failed to displace the ${ }^{125}$ I-GLP-1(736)amide binding, suggesting that GLP-1(7-36)amide and glucagon have separated receptors.
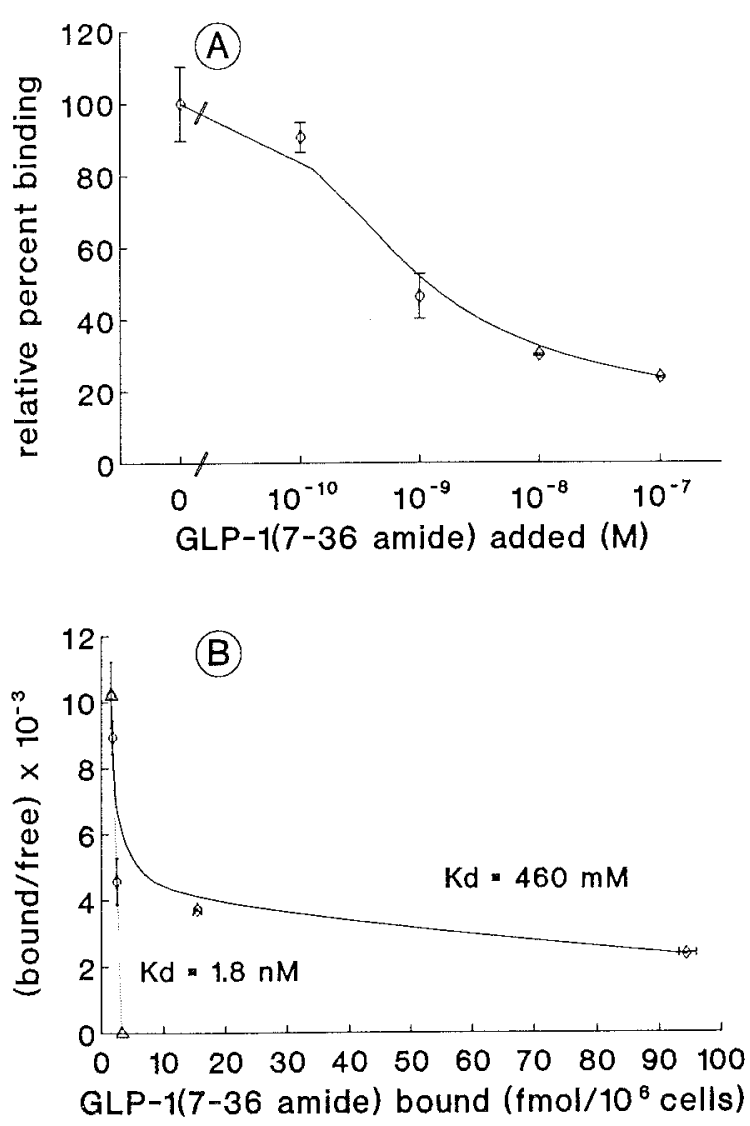

Fig. 4 A: Displacement of the specific binding of ${ }^{125} \mathrm{I}-$ GLP-1(7-36)amide to normal rat islet cells $\left(0.25 \times 10^{6}\right.$ cells/ml) by increasing concentrations of GLP-1(736) amide $\left(0-10^{-7} \mathrm{M}\right)$. Data are shown as mean \pm SEM $(n=2-5)$. B: Scatchard plot of the specific binding of ${ }^{125} \mathrm{I}$ GLP-1(7-36)amide to normal rat islet cells $\left(1 \times 10^{6}\right.$ cells/ $100 \mu \mathrm{l})$.

This work was supported by grants from Fondo de Investigaciones Sanitarias (FIS 90/0230), and Dirección General de Investigación Científica y Técnica (DGICYT, 90/0118). We thank Dr C. D. Wollheim for the supply of a batch of high insulin content RINm $5 \mathrm{~F}$ cells. We are grateful to Ms G. Calvo for skillful maintenance of cells line and to Ms P. Illana for excellent secretarial assistance. S.G. and E.F. are Research Fellows of Fundación Conchita Rábago de Jiménez Díaz and M.A.T. of Fondo de Investigaciones Sanitarias de la Seguridad Social.

Received 23 June 1991; and accepted I July 1991

\section{REFERENCES}

1. Bell G. I., Sanchez-Pescador R., Laybourn P. J. and NAJARIAN R. C. (1983) Exon duplication and divergence in the human preproglucagon gene. Nature 304, 368-371 
2. Bhathena S. J., Oie H. K., Gazdar A. F., Voyles N. R., WILKINS S. D. and RECANT L. (1982) Insulin, glucagon, and somatostatin receptors on cultured cells and clones from rat islet cell tumor. Diabetes 31, 521-531

3. Gazdar A. F., Chick W. L., Oie H. K., Sims H. L., King D. L., Weir G. C. and Lauris V. (1980) Continuous, clonal, insulin- and somatostatin-secreting cell lines established from a transplantable rat islet cell tumor. Proc. Natl. Acad. Sci. USA 77, 3519-3523

4. Giroix M. H., Malaisse-Lagae F., Sener A. and Malaisse W. J. (1985) Hexose metabolism in pancreatic islets. Galactose transport, phosphorylation and oxidation. Mol. Cell. Biochem. 66, 61-64

5. Göke R., Trautmann M. E., Haus E., Richter G., Fehmann H.-C., Arnold R. and GöKe B. (1989) Signal transmission after GLP-1(7-36)amide binding in RINm5F cells. Amer: J. Physiol. 257, G397-G401

6. GöKE R. and Conlon J. M. (1988) Receptors for glucagonlike peptide-1(7-37) amide on rat insulinoma-derived cells. J. Endocrinol. 116, 357-362

7. Heinrich G., Gros P. and Habener J. F. (1984) Glucagon gene sequence: four of six exons encode separate functional domains of rat preproglucagon. J. Biol. Chem. 4082 4087

8. Holst J. J., Ørskov C., VaGn Nielsen O. and Schwartz T. W. (1987) Truncated glucagon-like peptide I, an insulinreleasing hormone from distal gut. FEBS Lett. 211, 169-174

9. Kreymann B., Williamse G., Ghatei M. A. and Bloom S. R. (1987) Glucagon-like peptide-1 7-36: A physiological incretin in man. Lancet II, 1300-1304

10. Mojsov S., Heinrich G., Wilson I. B., Ravazzola M., OrCi L. and HABener J. F. (1986) Preproglucagon gene expression in pancreas and intestine diversifies at the level of post-translational processing. J. Biol. Chem. 261, 1188011889
11. Mojsov S., Kopczynski M. G. and Habener J. F. (1990) Both amidated and nonamidated forms of glucagon-like peptide $I$ are synthesized in the rat intestine and the pancreas. J. Biol. Chem. 265, 8001-8008

12. Novak U., Wilks A., Buell G. and McEwen S. (1987) Identical mRNA for preproglucagon in pancreas and gut. Eur: J. Biochem. 164, 553-558

13. Ørskov C., Bersani M., Johnsen A.H., Hojrup P. and Holst J. J. (1989) Complete sequences of glucagon-like peptide-1 from human and pig small intestine. J. Biol. Chem. 264, 12826-12829

14. ORsKov C. and Nielsen J. H. (1988) Truncated glucagonlike peptide-1 (proglucagon 78-107 amide), an intestinal insulin-releasing peptide, has specific receptors on rat insulinoma cells (RIN 5AH). FEBS Lett. 229, 175-178

15. Pipeleers D. G. and Pipeleers-Marichal M. A. (1981) A method for the purification of single A, B and D cells and for the isolation of coupled cells from isolated rat islets. Diabetologia 20, 654-663

16. Schmidt W. E., Siegel E. G. and Creutzfeldt W. (1985) Glucagon-like peptide-1 but not glucagon-like peptide-2 stimulates insulin release from isolated rat pancreatic islets. Diabetologia 28, 704-707

17. Suzuki S., Kawai K., Ohashi S., Mukai H. and Yamashita K. (1989) Comparison of the effects of various C-terminal and $\mathrm{N}$-terminal fragment peptides of glucagon-like peptide1 on insulin and glucagon release from the isolated perfused rat pancreas. Endocrinology 125, 3109-3114

18. Valverde I., Barreto M. and Malaisse W. J. (1988) Stimulation by D-glucose of protein biosynthesis in tumoral insulin- producing cells (RINm5F line). Endocrinology 122, 1443-1448

19. Wollheim C. B. and Pozzan T. (1984) Correlation between cytosolic free $\mathrm{Ca}^{2+}$ and insulin release in an insulin-secreting cell line. J. Biol. Chem. 259, 2262-2267 